\title{
Tolerance to somatostatin analogue in a preterm infant with islet cell dysregulation syndrome
}

\author{
J M Hawdon, M P Ward Platt, W H Lamb, A Aynsley-Green
}

\begin{abstract}
An infant of 31 weeks' gestation presented with refractory neonatal hypoglycaemia secondary to islet cell dysregulation. Treatment was started with somatostatin analogue and his glycaemic control improved initially. Tolerance developed, however, in that the dose required to maintain control increased by a factor of 40 . The infant subsequently underwent pancreatectomy. It is safe to use somatostatin analogue in a preterm infant, but tolerance to the drug rapidly develops.
\end{abstract}

Somatostatin is being used increasingly to manage refractory hypoglycaemia caused by hyperinsulinism, usually as a short term treatment before pancreatectomy. In this report we describe the presentation of severe refractory hyperinsulinaemic hypoglycaemia secondary to islet cell dysregulation in a preterm infant, and the difficulties that we encountered when we treated him with somatostatin analogue.

\section{Case report}

The male infant of a 26 year old, single primigravida mother was born after spontaneous onset of labour and normal vaginal delivery at 31 weeks' gestation (judged by mother's dates and by ultrasonography). Episodes of fetal bradycardia were recorded during labour and there was evidence of retroplacental haemorrhage after delivery of the placenta. At birth the infant was hypotonic and bradycardic and required resuscitation with intermittent positive pressure ventilation for six minutes. The birth weight was $2490 \mathrm{~g}$ and the head circumference was $31 \mathrm{~cm}$ (both measurements above the 90th centile). There were no abnormal features, genitalia were normal, and the infant was not pigmented.

He was electively intubated and ventilated at
5 hours of age, and ventilation was continued apart from a brief, unsuccessful, trial of extubation at 30 hours.

At 1 hour of age laboratory blood glucose measurement was $<0.5 \mathrm{mmol} / \mathrm{l}$ before starting an intravenous infusion of dextrose $4 \mathrm{mg}$ glucose $/ \mathrm{kg} / \mathrm{minute}$. Hypoglycaemia persisted despite the rate of infusion being increased to 16 $\mathrm{mg}$ glucose $/ \mathrm{kg} / \mathrm{minute}$ a number of bolus doses of $10 \%$ dextrose being given. On day 3 he had generalised and focal convulsions, which were treated with phenobarbitone.

At 57 hours of age he was transferred to the regional neonatal unit. Biochemistry confirmed hyperinsulinaemic hypoglycaemia with total blood ketone body concentration of 0.02 $\mathrm{mmol} / \mathrm{l}$, non-esterified fatty acid concentration of $0.005 \mathrm{mmol} / \mathrm{l}$, and insulin concentration of $44.7 \mathrm{mU} / 1$ while hypoglycaemic. Cortisol and growth hormone concentrations on the first day of life were $1228 \mathrm{nmol} / \mathrm{l}$ and $17 \cdot 3 \mu \mathrm{U} / \mathrm{l}$, respectively. A central venous line was inserted so that hypertonic glucose solutions could be given and continuous nasogastric feeds were started. Subsequently the total energy intake that was required to prevent hypoglycaemia rose to a maximum of $1.59 \mathrm{MJ}(380 \mathrm{kcal}) / \mathrm{kg} /$ day, which was given as $20 \%$ dextrose intravenously and Prematalac supplemented with Caloreen through the nasogastric tube. Glucagon given intramuscularly resulted in a transient glycaemic response, which supported the diagnosis of hyperinsulinism. Diazoxide and chlorothiazide given orally also had temporary glycaemic effects.

On day 10, treatment with somatostatin analogue (Sandostatin, Sandoz) was started, initially as boluses of $2.5 \mu \mathrm{g}$ given subcutaneously every four hours. The biochemical response to the first dose is shown in the table. After this favourable initial response, progressively larger bolus doses were required to maintain normoglycaemia and a subcutaneous infusion was
Department of Child Health, Princess Mary Hospital, Newcastle upon Tyne NE2 3BD J M Hawdon M P Ward Platt A Aynsley-Green Bishop Auckland General Hospital, Co Durham W H Lamb Correspondence to: Dr Hawdon.

Accepted 17 October 1990
Biochemical response to $2 \cdot 5 \mu \mathrm{g}$ Sandostatin given subcutaneously

\begin{tabular}{|c|c|c|c|c|c|c|}
\hline & \multicolumn{6}{|c|}{ Time after injection (hours) } \\
\hline & 0 & 1 & 2 & 3 & 4 & 5 \\
\hline $\begin{array}{l}\text { Glucose* } \\
\text { Pyruvate* } \\
\beta \text { hydroxybutyrate* } \\
\text { Acetoacetate* } \\
\text { Glycerol* }^{*} \\
\text { Alanine }^{*} \\
\text { Lactate } \\
\text { Non-esterified fatty acid* } \\
\text { Insulin (mU/l) }\end{array}$ & $\begin{array}{l}1 \cdot 50 \\
0 \cdot 07 \\
0 \cdot 01 \\
0 \cdot 05 \\
0 \cdot 28 \\
0 \cdot 30 \\
1 \cdot 55 \\
0 \cdot 10 \\
37 \cdot 4\end{array}$ & $\begin{array}{l}7 \cdot 80 \\
0 \cdot 06 \\
0 \cdot 01 \\
0 \cdot 04 \\
0 \cdot 22 \\
0 \cdot 27 \\
1 \cdot 12 \\
0 \cdot 09 \\
6 \cdot 3\end{array}$ & $\begin{array}{l}0 \cdot 08 \\
0 \cdot 01 \\
0 \cdot 05 \\
0 \cdot 25 \\
0 \cdot 36 \\
1 \cdot 40 \\
0 \cdot 11 \\
10 \cdot 4\end{array}$ & $\begin{array}{c}5 \cdot 94 \\
0 \cdot 09 \\
0 \cdot 01 \\
0 \cdot 04 \\
0 \cdot 27 \\
0 \cdot 37 \\
2 \cdot 39 \\
0 \cdot 09 \\
15 \cdot 3\end{array}$ & $\begin{array}{l}4 \cdot 26 \\
0 \cdot 08 \\
0 \cdot 01 \\
0 \cdot 06 \\
0 \cdot 28 \\
0 \cdot 39 \\
2 \cdot 31 \\
0 \cdot 08 \\
13 \cdot 1\end{array}$ & $\begin{array}{l}4 \cdot 20 \\
0 \cdot 08 \\
0 \cdot 01 \\
0 \cdot 04 \\
0 \cdot 26 \\
0 \cdot 38 \\
2 \cdot 06 \\
0 \cdot 18 \\
19 \cdot 2\end{array}$ \\
\hline
\end{tabular}

*All concentrations are $\mathrm{mmol} / \mathrm{l}$. 


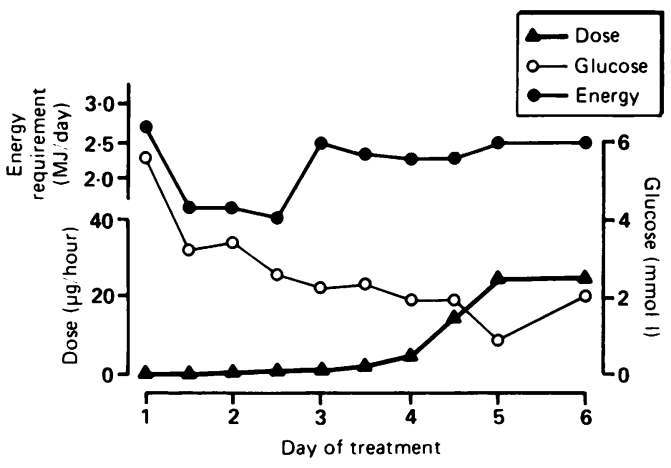

Dose of Sandostatin, blood glucose concentration, and energy requirement during treatment.

begun. Hypoglycaemia and the need for a high energy intake persisted, however, despite increasing the dose to $25 \mu \mathrm{g} /$ hour (figure).

During this period he developed heart failure secondary to fluid overload, ventilatory requirements remained high with radiographic appearances of respiratory distress syndrome, and the infant remained irritable. Cerebral ultrasonography showed increased echogenicity in both hemispheres, and there were multifocal discharges on electroencephalography.

As the hypoglycaemia was proving to be refractory to medical treatment, a $99 \%$ pancreatectomy was performed under general anaesthesia on day 15. Histological examination confirmed the appearances of 'nesidioblastosis', with disorganisation of islet architecture and the presence of insulin secreting cells in the duct epithelium of the exocrine pancreas. Sandostatin infusion was discontinued at induction of anaesthesia and hydrocortisone was given because of the suppressive effect of Sandostatin on adrenocorticotrophic hormone secretion. After operation, he was hypoglycaemic and then hyperglycaemic, but subsequently there was progressive reduction in the intravenous glucose intake to $7 \mathrm{mg}$ glucose $/ \mathrm{kg} /$ minute, and full nasogastric feeding was established on the seventh postoperative day. Insulin was not required.

The clinical improvement was confirmed by the biochemical findings (glucose concentration $8.7 \mathrm{mmol} / \mathrm{l}$, total ketone bodies $0.10 \mathrm{mmol} / \mathrm{l}$, glycerol $0.31 \mathrm{mmol} / \mathrm{l}$, and insulin $<1.0 \mathrm{mU} / \mathrm{l})$. There was no clinical or biochemical evidence that Sandostatin had had any adverse endocrinological effects, cortisol concentrations during and four weeks after treatment were $189 \mathrm{nmol} / \mathrm{l}$ and $205 \mathrm{nmol} / \mathrm{l}$, respectively, and thyroid function tests during treatment were within normal neonatal ranges (thyroxine $97 \mathrm{nmol} / \mathrm{l}$, triiodothyronine uptake $32 \%$, and free thyroxine index $31 \%$ ). The baby was extubated into air on the fourth postoperative day.

He was discharged home at the age of 6 weeks (37 weeks corrected age), and bottle fed with a proprietary formula supplemented with pancreatic enzymes. Strict blood glucose monitoring has been carried out by his parents and, though he has had no episodes of symptomatic hypoglycaemia, home monitoring has shown a steady trend towards low blood glucose measurements despite his now being on a normal weaning diet. Since the age of 5 months diazox- ide $20 \mathrm{mg} / \mathrm{kg} /$ day and chlorothiazide $10 \mathrm{mg} / \mathrm{kg} /$ day have been required to maintain blood glucose concentrations between 2 and $4 \mathrm{mmol} / \mathrm{l}$. The baby's weight was on the 25 th centile at the time of writing and his head circumference was growing parallel to and just below the 50th centile. His developmental progress is appropriate for corrected gestational age, and he is a pleasant baby, though somewhat difficult to feed at times.

\section{Discussion}

Others authors have described the use of somatostatin in the control of neonatal hypoglycaemia secondary to the dysregulation syndromes of the endocrine pancreas, including 'nesidioblastosis' and $\beta$ cell adenoma. ${ }^{12}$ Similar doses to those that we describe have led to a prompt rise in blood glucose concentrations accompanied by a fall in plasma insulin. Aynsley-Green et al also described an increase in blood ketone bodies and glycerol after somatostatin infusion. ${ }^{3}$ The use of somatostatin is, however, limited by the need for continuous infusions, with hypoglycaemia developing rapidly as soon as the infusion is stopped. There is also concern about the effects of somatostatin on growth hormone, thyroid hormones, corticosteroids, and gut hormones in such young infants. ${ }^{3}$ Glucagon secretion is also suppressed during treatment, which may explain the disappointing results sometimes obtained. ${ }^{13}$ For this reason, it has been recommended that glucagon should be given concurrently with somatostatin. ${ }^{45}$ More recently the use of somatostatin analogue in the management of neonatal hypoglycaemia has been described. It is possible to give intermittent doses, as the analogue has a long half life, and it is claimed that despite suppression of growth hormone, long term treatment does not result in failure of growth. ${ }^{67}$

This case is unusual on two counts: the presentation of severe hyperinsulinism secondary to an anatomical abnormality of the pancreas in a very preterm infant, and the rapid development of tolerance to Sandostatin. Undoubtedly the management of severe hypoglycaemia was made more difficult by the other problems of prematurity, namely respiratory distress syndrome and respiratory failure. This prevented early establishment of high energy enteral feeds, and left the infant totally dependent on parenteral glucose to maintain substrate availability.

The tolerance to somatostatin analogue that developed was so dramatic (a 40-fold increase in dose in three days) that it almost amounted to a failure of treatment. It allowed no reduction in energy intake, and barely maintained normoglycaemia. Such a phenomenon has not to our knowledge previously been reported, and was surprising in this case in view of the good response to the first dose.

Somatostatin is a potent inhibitor of endocrine secretion and may be expected to have widespread effects. Of particular concern in the preterm neonate are effects on gut motility and thyroid function. No deleterious effects were observed on gut function, however, and thyroid function tests remained normal, as might be 
expected from the long half life of thyroxine. The plasma cortisol concentration must be interpreted with caution, as the presence of an apparently normal concentration cannot be taken to predict an appropriate stress response. ${ }^{8}$ It was for this reason that steroids were given during the operation.

We recommend that, with appropriate monitoring of the metabolic and endocrine state, somatostatin analogue can be used in the short term management of hyperinsulinaemic hypoglycaemia secondary to islet cell dysregulation. In view of the tolerance to the drug that developed, however, it is unlikely that its use will obviate the need for a definitive operation.

1 Hirsch HJ, Loo S, Evans N, Crigler RNJ Jr, Filler RM, Gabbay KH. Hypoglycemia of infancy and nesidioblastosis. Studies with somatostatin. N Engl f Med 1977;296: $1323-6$.
2 Kitson HF, McCrossin RB, Jiminez M, Middleton A, Silink M. Somatostatin treatment of insulin excess due to $\beta$-cell adenoma in a neonate. $\mathcal{J}$ Pediatr 1980;96:145-8.

3 Aynsley-Green A, Barnes ND, Adrian TE, Kingston J, Boyes S, Bloom SR. Effect of somatostatin infusion on intermediary metabolites and enteroinsular hormone release in infants with hyperinsulinaemic hypoglycaemia.
Acta Paediatr Scand 1981;70:889-95.

4 Bloomgarden ZT, Sundell H, Rogers LW, O'Neill JA, Lijenquist E. Treatment of intractable neonatal hypoglycemia with somatostatin plus glucagon. $\mathcal{F}$ Pediatr 1980;96: 148-51.

5 Bougneres P-F, Landir F, Garnier P, Job J-C, Chaussin $\mathrm{J}-\mathrm{L}$. Treatment of insulin excess by continuous subcutaneous infusion of somatostatin and glucagon in an infant. $\mathcal{f}$ Pediatr 1985;106:792-4.

6 Jackson JA, Hahn HB Jr, Oltorf CE, O'Dorisio TM, Vinik AI. Long term treatment of refractory neonatal hypoglyce111:548-51.

7 Wilson DC, Carson DJ, Quinn RJM. Long term use of somatostatin analogue SMS 201-995 in the treatment of hypoglycaemia due to nesidioblastosis. Acta Paediatr Scand 1988;77:467-70.

8 Anand KJS, Sippell WG, Aynsley-Green A. Randomised trial of fentanyl anaesthesia in preterm infants undergoing surgery: effects on stress response. Lancet 1987;i:243-8. 